Florida International University FIU Digital Commons

6-10-2015

\title{
The Hospitality Cooperative Education: What are the Benefits for Industry Partners?
}

YING WANG

ywang092@fiu.edu

DOI: $10.25148 /$ etd.FIDC000078

Follow this and additional works at: https://digitalcommons.fiu.edu/etd

Part of the Educational Assessment, Evaluation, and Research Commons, and the Other Social and Behavioral Sciences Commons

\section{Recommended Citation}

WANG, YING, "The Hospitality Cooperative Education: What are the Benefits for Industry Partners?" (2015). FIU Electronic Theses and Dissertations. 2221.

https://digitalcommons.fiu.edu/etd/2221

This work is brought to you for free and open access by the University Graduate School at FIU Digital Commons. It has been accepted for inclusion in FIU Electronic Theses and Dissertations by an authorized administrator of FIU Digital Commons. For more information, please contact dcc@fiu.edu. 


\section{FLORIDA INTERNATIONAL UNIVERSITY}

Miami, Florida

THE HOSPITALITY COOPERATIVE EDUCATION: WHAT ARE THE BENEFITS

FOR INDUSTRY PARTNERS

A thesis submitted in partial fulfillment of the

requirements for the degree of

MASTER OF SCIENCE

in

HOSPITALITY MANAGEMENT

by

Ying Wang

2015 


\section{To: Dean Mike Hampton}

School of Hospitality and Tourism Management

This thesis, written by Ying Wang, and entitled The Hospitality Cooperative Education: What are the Benefits for Industry Partners, having been approved in respect to style and intellectual content, is referred to you for judgment.

We have read this thesis and recommend that it be approved.

Myongjee Yoo

Carolin Lusby

Miranda Kitterlin, Major Professor

Date of Defense: June 10, 2015

The thesis of Ying Wang is approved.

Dean Mike Hampton School of Hospitality and Tourism Management

Dean Lakshmi N. Reddi

University Graduate School

Florida International University, 2015 


\section{ACKNOWLEDGMENTS}

I would like to express the deepest appreciation to my chair professor, Dr. Miranda Kitterlin, who has continually and persuasively conveyed a spirit of adventure in regard to research, and an excitement in regard to a tremendous mentor. Without her supervision and constant help, this thesis would not have been possible. I would like to thank you for encouraging my research and for allowing me grow as a researcher. I would also like to express my special appreciation and thanks to Dr. Myongjee Yoo and Dr. Carolin Lusby for serving as my committee members. I am thankful for their aspiring guidance and invaluably constructive criticism during the research work. Thank you for your priceless advice and brilliant comments. You made my work even better than I expected.

A special thanks to my family who encouraged me and my friends who supported me in writing. 


\section{ABSTRACT OF THE THESIS \\ THE HOSPITALITY COOPERATIVE EDUCATION: WHAT ARE THE BENEFITS FOR INDUSTRY PARTNERS}

by

Ying Wang

Florida International University, 2015

Miami, Florida

\section{Professor Miranda Kitterlin, Major Professor}

Cooperative education program was introduced into undergraduate hospitality degree program to help students be better prepared for their careers. A cooperative partnership between the industry and universities results in both sides receiving benefits. This study identifies the benefits industry partners receive from a cooperative education program. The implications of these benefits leads to the evaluation of hospitality cooperative education. From the results of the evaluation, recommendations are proposed for redesigning the cooperative education program. 


\section{TABLE OF CONTENTS}

CHAPTER

PAGE

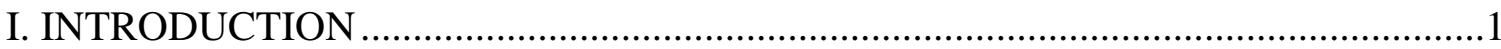

II. LITERATURE REVIEW ……………..................................................................

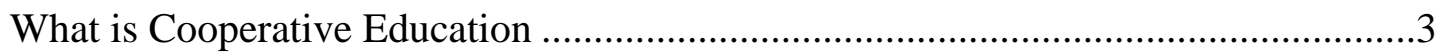

The Development of Cooperative Education.............................................................

The Purpose of Cooperative Education ...................................................................6

The Benefits of Cooperative Education.......................................................................6

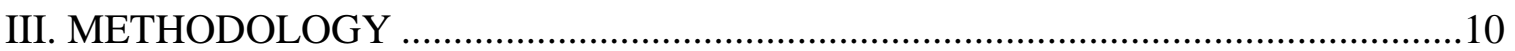

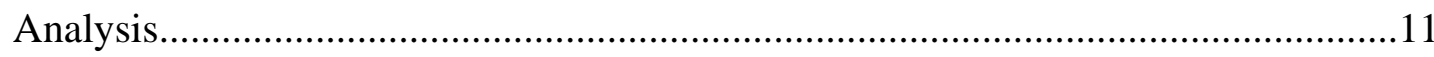

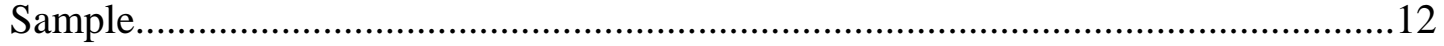

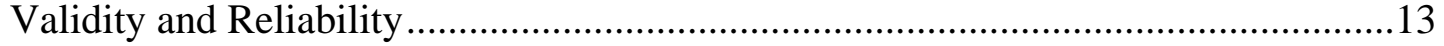

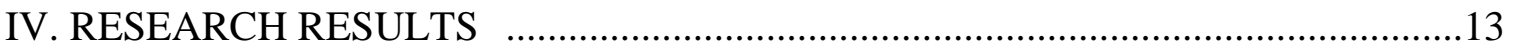

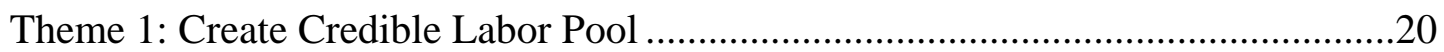

Theme 2: New Energy ……………………………….....................................22

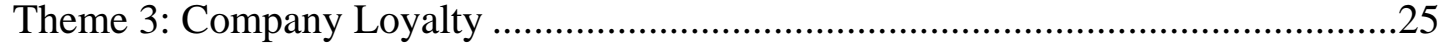

Theme 4: Altruistic Social Responsibility ...........................................................26

Theme 5: Mutual Learning ....................................................................................2

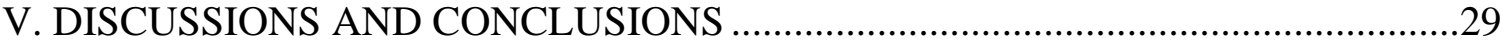

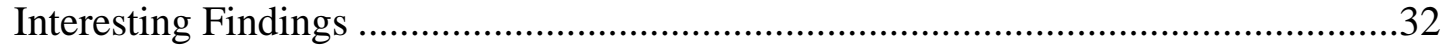

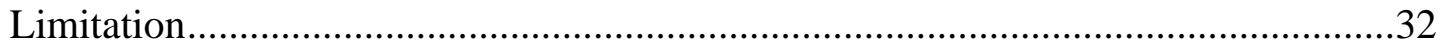

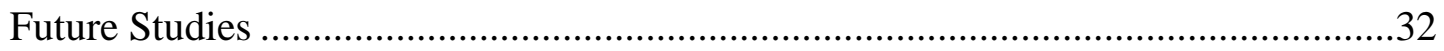

LIST OF REFERENCES ................................................................................... 


\section{CHAPTER I \\ INTRODUCTION}

The hospitality industry is a dynamic industry that is constantly evolving at a fairly rapid pace. At the early stage, hospitality appeared as a different industry and was studied solely by individual operators within each work sector (i.e. lodging, events, restaurants.) and by individual scholars (Breen, 2002). Meanwhile, a growth in the hospitality industry that involved travel, service, conventions, leisure and business activities, had contributed to this field and urged the development of vocational qualification education (Fidgeon, 2010). Teichler (1992) has introduced four stages in education: basic education, secondary education, tertiary education and professional education. Vocational qualification was considered as the fourth stage due to its explicit professional purposes. It was not until the1960s, hospitality education emerged with a clear area of study, which included an undergraduate discipline and strong focus on research. Stimulated by economy activities and service standards, the hospitality education had achieved great progress; as more formal hospitality education programs became established, the number of students willing to enroll in these education programs for a better employment prospect increased (Fidgeon, 2010).

Within the technology setting, education and business are involved in a changing process, where the exchange of information and communication occurs at a higher speed and in a much more complicated way. Establishing a partnership between an educational institution and business organization is an effective method of achieving resource sharing. Not only does this benefit the educational institution by developing efficient teaching programs, but it also benefits business insiders by building up a qualified labor pool 
(Sigala \& Baum, 2003). Universities are utilizing a new approach; shifting from book-based theory to workplace practice-based integrated learning. Meanwhile, the hospitality industry achieved professionalism by establishing formal educational training and raising industry service standards, as well as enhancing their competitive competence, which indicates an overall improvement of requirements for the industry as a whole in both the educational program and recruiting process (Harris and Jago, 2001).

Industry demand for professional skills by industry encouraged the emergence of university and industry collaboration. Universities desire to offer students professional experience opportunities in the form of internships. Industry partners seek university graduates who are better prepared for the workplace. Lam and Ching (2007) suggested internships, as one way to achieve a partnership with the industry as it offers an excellent stage for the student to integrate theoretical methods with workplace experience.

According to precious research, the results stressed various benefits for students, educational institutions, and industry partners. However, many studies have found plenty benefits for students who are involved in hospitality cooperative education whereas, fewer studies examine benefits for industry partners. With regards to significance, this study is needed because there have been few previous studies conducted to identify the benefits of industry from university partnerships (Leslie \& Richardson, 2000; Breen, 2002; Breen \& Hing, 2002; Frye \& Eicher, 2006); there appears to be a significant gap in the literature. By incorporating this collaboration between education and business, the benefits for both sides are significant enough for evaluation. However, this study is an exploratory research and nonrandom sampling technique is used. The twenty-three 
participants are limited in the geographic area as well. The further study is recommended for a bigger sample size so that the possible identified results can be more persuasive.

The purpose of this study is to identify benefits for industry partners, particular in hospitality industry, who are involved or have been involved in a cooperative program with an educational institution, and why they would like to continue the partnership in the future. The implications of these benefits leads to the evaluation of hospitality cooperative education. From the results of the evaluation, recommendations are proposed for redesigning the cooperative education program.

\section{CHAPTER II}

\section{LITERATURE REVIEW}

\section{What is Cooperative Education}

According to World Council and Assembly on Cooperative Education (1987), Cooperative Education is a strategic program of practical learning designed by an education institution in partnership with an industry organization, which offers relevant working experience. To be more precise, the cooperative education program provides work integrated learning experiences (Martin et. al., 2010) that would help students bridge the gap between their academic and professional career. The ultimate objective of cooperative education is to prepare students for their future career by offering relevant work experience opportunities. Cooperative education is applied in various industries (Breen, 2002). For this study, the cooperative education specifically focuses on the hospitality program, where university and industry partners share resources and collaborate together to create a course design in which education and training are jointly 
developed (Hase, 1997). Harris and Jago (2001) have indicated that in the hospitality industry, the connection between university and industry partners is perceived in a positive way, which has been seen as a significant stimulus to enhance professional standards.

\section{The Development of Cooperative Education}

"Businesses provide the world with goods and services in exchange for something of value" (Breen, 2002:3). Exchange encourages competition through the products that customers purchase as well as the profits that organizations eventually earn. Labor, one of the physical assets of business, is often overlooked by companies unless employees are encouraged to learn and train (De Geus, 1997). To meet the competitive environment, companies now appear to evolve in enhancing their labor effectiveness by requiring a more extensive knowledge background and raising standards. In fact, Drucker (1997) claimed the supply of knowledgeable workers is the only comparative advantage in developed countries. A healthy environment has been shaped; knowledge can be applied into products and services to meet industry demand. This idea proved the intimate relationship between knowledge and business performance, which indicates that the workforce under high-quality standards creates longevity for companies to survive (Breen, 2002). To develop labor capacity, companies need to establish a channel to obtain knowledgeable employees. Industry organizations can find more opportunities to explore qualified candidates by cooperating with universities.

Universities, as contributors to the national wealth (Wilson, 1997), have to reshape their ultimate objectives of education. In order to keep high demands of the market, universities now make practical learning as their priority. Practical learning is an 
approach to learning that focuses more on experience and reflection as a means of professional education, according to Gruman \& Reavley (2009). Since the business environment becomes more complex, practical learning becomes more important than ever before. Internships, as one approach of practical learning, are a common illustration of cooperative effort. Being recognized by the public, "internship enables students to implement textbook theoretical knowledge in the actual workplace" (Lam \& Ching, 2007:6). By establishing a cooperative relationship with industry organizations, universities obtain efficient access to opportunities for workplace experience for their students to achieve pre-career training.

Wallace and Ipson (1992) proposed that the future workplace requires higher competence, communication skills, and group effectiveness. Industry organizations intend to outsource their initial training instead of conducting the training themselves. As a result, the demand for outside vendors, who provide training services, will rapidly grow. Among those vendors, universities seem to be a safer alternative compared to other paid training agencies. Cooperative education links universities and businesses together and establishes a stable network for companies to obtain specifically trained talent with credible knowledge background. In turn, the universities acquire adequate accesses to human resources. In a long-term perspective, Cooperative Education is a sustainable relationship to benefit both parties: industry organizations and universities.

The partnership between the industry and the university aims at industrial placement (Busby, 2005), so that cooperative education programs are developed with the required practical experience (supervised working experience or internship) to complete the graduation (King, 1994). 


\section{The Purpose of Cooperative Education}

According to Leslie \& Richardson (2000), it has been a great challenge for an organization to find and retain qualified candidates. What the industry organization is looking for is not only about the candidates' personal development and educational background, but also the candidates' industry experience and the understanding of the operation.

Moreover, cooperative education is the way to establish a linkage between the university and the industry. This linkage is a win-win method of achieving objectives for both parties; the industry partner is often seeking cheap labor whereas the educational institution is seeking a structured training experience for the student (Solent \& Cooper, 2007: 67).

\section{The Benefits of Cooperative Education}

Cooperative education is "considered as a significant link between education and the industry" (Dickerson \& Kline, 2008:7). Cooperative education is just the right relationship that builds up a dual connection and integrates academic theories with real practice in the workplace (Kiser \& Partlow, 1999). Although the cooperative education program requirement may vary from completion of one hour of service to a more lengthy duration of position and employment, they all hold the same concept-to meet the industry demand (Powers \& Riegel, 1993). Reported by Tesone and Ricci (2005), 87\% of the hospitality industry organizations prefer to have work-based experience candidates. Students, as the largest group within the university, are initial beneficiaries of the program. On the other hand, industry partners receive the benefits over time as the students' roles become even more significant due to their long-term development. 
Leslie \& Richardson (2000) indicated that the cooperative partnership brings benefits for all parties include students, industry partners and the education institution. And the benefits are well documented.

\section{Benefits for Students}

Valid preview of industry. Cooperative education programs offer a valid preview of the real industry, which will be helpful for students to better prepare for their future employment according to Van Hoof (2000). The preview includes industry salary, retention, benefits, and working hours (Dickerson \& Kline, 2008). As mentioned above, the Cooperative Education program is a relationship where the industry shares human resources with university students, while universities share developing talent with industry. Within realistic practice prior to official employment, students get the chance to preview the real operation of the industry to get a glimpse of the real working condition and to test whether the industry is the right fit (Busby \& Gibson, 2010). Additionally stated by Roberts (2003), by participating in Cooperative Education Programs, the knowledge level enhances when the learning content links with the real-life situation. As a result, students previewing the industry condition while joined to the Cooperative Education Programs may acquire a solid background of knowledge.

Develop personal skills. Emphasized by Gryski and O'Toole (1987), Cooperative Education programs offer a valid stage for students to develop their personal skills. To evolve into teamwork and operation projects, students start to become aware of ethical concerns around business operations and have a sense of efficacy. The benefits also supported by Marlin-Bennett (2002) of developing job skills, problem-solving skills, and decision-making skills are obvious outcomes of internship or working experience, which 
is offered by the Cooperative Education program. Gillin and Beissel (1984) also mentioned this partnership enables students to improve self-confidence, self-concept, and social skills. Those personal skills learned from the experience will increase their integrated professional competency and make them ready for new upcoming employment. Petrillose and Montgomery (1998) specifically address that Cooperative education programs make students more marketable for their career immediately after graduation by enhancing their resume making skills. Early professional outcomes of Cooperative Education programs in hospitality management have apparently had a positive impact on students.

Develop career opportunities. By cooperating with industry organizations, universities obtain more human resources to offer students more networking opportunities after their graduation (Dickerson \& Kline, 2008). These networking opportunities are what the students demand because those can be a good start or a key to success in their career. Also in their research, the statistics show that students who graduate from Cooperative Education programs tend to have higher starting salaries and higher job satisfaction. Another significant outcome is that those student groups have a greater percentage of getting into a management position. Similar research by Coco (2000), found that students who participate in Cooperative Education programs tend to acquire job advancement more quickly than students that do not participate in Cooperative Education programs. Both studies have shown consistency of early career success, and the benefits for students are obviously clear. 


\section{Benefits for Industry Partners}

Secure Recruitment Candidates. Hemington (1999) implied that higher human resource demand makes the labor intensive market less secure and more competitive. Within Cooperative Education programs, the university becomes a reliable backup of qualified candidates for industry partners. With regards to job placement within the industry, most organizations would like to choose a trusted individual or partner instead of an unknown individual recruited from a huge labor market. Busby and Gibson (2010) described a phenomenon in which hotels prefer to recruit the candidates from the same university, especially when previous hires received promotions to key positions. Generally, this is because of the familiar performance and higher credibility. Cooperative education minimizes the potential risk of hiring an unknown entity (Wallace \& Ipson,1992) and improves staff selection security (Breen, 2002). In addition, with better qualified candidates and employees, the entire industry get improved with strengthen competitiveness (Breen \& Hing, 2002).

Enhance Organization Progression. By participating in Cooperative Education, industry organizations have motivated students to be future candidates of employment, which is helpful for individuals to achieve personal success, as well as organizational progression (Hemmington, 1999). Organizations maintain higher educational attainment by university student selection (Teichler, 1992). As an advantage, it enhances organizations' competencies and performances (Breen \& Hing, 2002). Waryszak (1999) also proposed the same idea that through the Cooperative Education, hotels can lower their turnover rate in human resources and training for better employees for a longer period. Besides, Cooperative Education helps industry organizations build employee 
loyalty. Since students have received recognition in their early career, as well as obtained workplace experience with industry partners, they may tend to choose that industry partner to start their career. Bereday (1973) indicated that Cooperative Education is another method of achieving commercial goals. Therefore, the initial awareness of industry partners has had a strong impact on the students' early career and has become a priority after graduation.

According to Leslie and Richardson (2000:490), the benefits listed for industry partners also include lower labor cost and the "potential opportunity to undertake research by the student and sported by institution.”

\section{CHAPTER III}

\section{METHODOLOGY}

The use of qualitative research methodologies to investigate the context in which individual behaviors take place is imperative to gaining insights into cause and effect relationships, studying special populations, and developing sound quantitative research instruments (Achterberg \& Arendt, 2008). In hospitality research, the need for qualitative research has been widely recognized (Kwortnik, 2003). The purpose of this study is to investigate the benefits for industry partners involved in Cooperative Education programs with universities. Additionally, with the results, a solid evaluation for hospitality Cooperative Education programs may be developed. Because of the insufficiency of previous research available on the hospitality cooperative education, particularly regarding the benefits for industry partners, there is indication that a qualitative approach is a proper method for this study. Specifically, an inductive thematic analysis was applied to identify the benefits for industry insiders, including recruiters and industry partners. 
Due to the nature of hospitality industry, the working shift causes time inconvenience for our participants to schedule interviews, email interview works better for participants and used instead for this study as they were more ideal for the study participants. Interviews were performed in an open-ended format, which allows participants to answer without restrictions. Interviews were performed in a conversational manner with guiding questions. Every participant was asked the following initial questions: 1) What characteristics should a student candidate have to meet the requirements of recruitment for an internship/position in the hospitality and tourism? 2) If you offer an internship, how do you evaluate the students? 3) What do you think about university-industry partnerships overall? 4) What benefits does your company get from partnering with a university? What benefits do you get personally from the partnership? What are the drawbacks of this partnership? 5) Would you be willing to join more university-industry partnerships in the future? Why or why not?

\section{Analysis}

First, one unstructured interview with a restaurant manager was conducted to develop the interview guiding questions that was used in the following email interview. Questions included "What characteristics are looking for by the industry from the graduate students?" and "What benefits does industry receive from the partnership with universities?" Based on the answers, guiding questions were developed for the email interviews.

Email invitations to participate in the email interview were sent to industry partners, internship providers, university alumni and advisory board members. After receiving the participation agreement email from participants the online informed consent form was 
attached to the reply email, as well as an abstract of the study and the interview guiding questions.

After sending out the first 8 interview emails, the interview questions were edited accordingly for flow and clarity. The rest of the participants were emailed the revised, finalized interview questions.

Data from the first 5 interviews were analyzed separately by three independent researchers using microanalysis (aka line-by-line coding) (Strauss \& Corbin, 1998) to identify key codes, which were categorized into groups by similar meaning in order to develop coding themes. The grouped coding themes were used to analyze the remaining responses, and new themes were added during the later analysis. Themes were discussed by the three independent researchers and emailed back to participants once they reached a final consensus, thus completing triangulation. Data collection was concluded once no new themes emerge (i.e. theoretical saturation) (Strauss \& Corbin, 1998).

\section{Sample}

Requirements for participation in this study were: 1) a person must be in a position in to the hospitality industry, and 2) have been involved with a cooperative education program with a university. A total of 210 participation invitations were sent out through email, as well as the contacts of South Florida university hospitality and tourism programs, including internship providers, advisory board members, and hospitality insiders.

Participation was voluntary and confidential, and involved the completion of a 15 to 30-minute email interview. This data collection approach was selected to encourage participants to share their thoughts, experiences, and the benefits that they perceive from 
the Cooperative Education program. Each interview was conducted through email and recorded by text. Each researcher read, analyzed and coded the data independently by using inductive thematic analysis; the independent coding was performed to strengthen reliability (Braun and Clarke, 2006).

First, each researcher read the interview transcripts and deciphered codes that have significant meaning to the research topic. Next, each researcher developed grouped themes with similar meaning codes. Then, each researcher compared their independently derived codes and themes and came to a consensus. Themes were not finalized until 100-percent agreement was reached by all three independent researchers.

\section{Validity and Reliability}

To improve the validity and reliability of the data, each researcher evaluated the interview transcripts and independently coded them. Next, the meaningful codes and grouped themes were discussed by all researchers and were finalized with an agreement of all researchers (Crawford, 2013). In addition, all themes were emailed back to participants to get their consensus that the concluded themes were what their responses actually mean.

\section{CHAPTER IV}

\section{RESEARCH RESULTS}

Twenty-three participants were involved in this study and provided valid responses. The table listed below shows the demographic information of all participants. Three of the 23 participants did not respond to the demographic questions.

\section{Table 1}




\begin{tabular}{|c|c|c|c|c|}
\hline Participant \# & Position & $\begin{array}{l}\text { Industry } \\
\text { Segment }\end{array}$ & $\begin{array}{c}\text { Years of } \\
\text { Hospitality } \\
\text { Work } \\
\text { Experience }\end{array}$ & $\begin{array}{c}\text { Years of } \\
\text { University } \\
\text { Partnership }\end{array}$ \\
\hline Participant \#1 & $\begin{array}{c}\text { Human Resource } \\
\text { Manager }\end{array}$ & Lodging & $6+$ & 4 \\
\hline Participant \#2 & $\begin{array}{c}\text { Director of Business and } \\
\text { Digital Innovation }\end{array}$ & $\begin{array}{c}\text { Sports and } \\
\text { Entertainment }\end{array}$ & $3+$ & 2 \\
\hline Participant \#3 & Employment Manager & Lodging & 15 & 5 \\
\hline Participant \#4 & $\begin{array}{c}\text { Director of Human } \\
\text { Resources }\end{array}$ & Lodging & 12 & 1.5 \\
\hline Participant \#5 & No Response & No Response & $\begin{array}{c}\text { No } \\
\text { Response }\end{array}$ & $\begin{array}{c}\text { No } \\
\text { Response }\end{array}$ \\
\hline Participant \#6 & General Manager & Food service & 26 & 1 \\
\hline Participant \#7 & $\begin{array}{c}\text { Corporate } \\
\text { Responsibility } \\
\text { Department Head }\end{array}$ & Cruise & 19 & 5 \\
\hline Participant \#8 & General Manager & Lodging & 20 & 4 months \\
\hline
\end{tabular}




\begin{tabular}{|c|c|c|c|c|}
\hline Participant \#9 & $\begin{array}{c}\text { Executive Vice } \\
\text { President }\end{array}$ & Lodging & 45 & 45 \\
\hline Participant \#10 & No Response & No Response & $\begin{array}{c}\text { No } \\
\text { Response }\end{array}$ & $\begin{array}{c}\text { No } \\
\text { Response }\end{array}$ \\
\hline Participant \#11 & Director of Finance & Food Service & 12 & 7 \\
\hline Participant \#12 & No Response & No Response & $\begin{array}{c}\text { No } \\
\text { Response }\end{array}$ & $\begin{array}{c}\text { No } \\
\text { Response }\end{array}$ \\
\hline Participant \#13 & $\begin{array}{c}\text { Director of Talent } \\
\text { Management }\end{array}$ & Lodging & 16 & 8 \\
\hline Participant \#14 & $\begin{array}{c}\text { Sales and Event } \\
\text { Manager }\end{array}$ & Food Service & 12 & 1 \\
\hline Participant \#15 & $\begin{array}{c}\text { Learning and } \\
\text { Development Assistant/ } \\
\text { Coordinator }\end{array}$ & Lodging & 9 & 3 \\
\hline Participant \#16 & Front Office Supervisor & Lodging & 9 & 2 \\
\hline Participant \#17 & Business Owner & Food Service & 10 & $<1$ \\
\hline Participant \#18 & $\begin{array}{c}\text { Assistant General } \\
\text { Manager }\end{array}$ & Lodging & 14 & 1 \\
\hline
\end{tabular}




\begin{tabular}{|l|c|c|c|c|}
\hline Participant \#19 & Director of Operations & Food Service & 17 & 5 \\
\hline Participant \#20 & Director of Academies & Education & 25 & 1 \\
\hline Participant \#21 & Assistant General & Lodging & 7 & 1 \\
\hline Participant \#22 & Associate Director of & Lodging & 17 & 8 \\
& Human Resources & & & \\
\hline Participant \#23 & Head Chef & Food Service & 22 & \\
\hline
\end{tabular}

“<” indicates "less than"

By analyzing the responses from all the participants from interview questions $1 \& 2$, five qualities industry partners are looking for when hiring gradates were identified. Table 2 provides the characteristics.

Interview Question 1: What characteristics should a student candidate have to meet the requirements of recruitment for an internship/position in hospitality and tourism?

Interview Questions 2: If you offer an internship, how do you evaluate the students?

Table 2

\begin{tabular}{|l|l|}
\hline \hline Characteristics & Summary \\
\hline Personality & Friendly; \\
& Outgoing; \\
\hline
\end{tabular}




\begin{tabular}{|c|c|}
\hline & $\begin{array}{l}\text { Inquisitive; } \\
\text { Patient; } \\
\text { Punctual }\end{array}$ \\
\hline Integrity & $\begin{array}{l}\text { Computer skills; } \\
\text { Learning capability; } \\
\text { Language skills; } \\
\text { Communication skills; } \\
\text { Professional; } \\
\text { Ability to work in teams; } \\
\text { Leadership capability; } \\
\text { Independent critical thinking }\end{array}$ \\
\hline Background & $\begin{array}{l}\text { Education background; } \\
\text { Related experience; } \\
\text { Records of achievement }\end{array}$ \\
\hline Enthusiasm & $\begin{array}{l}\text { Passion; } \\
\text { Energetics, } \\
\text { Strong interests; } \\
\text { Willing to devote themselves in the hospitality industry; } \\
\text { Open-minded }\end{array}$ \\
\hline Vision & $\begin{array}{l}\text { Ambitions; } \\
\text { Future plans; } \\
\text { Specific goals }\end{array}$ \\
\hline
\end{tabular}


Twenty-two of the 23 participants agreed that students who graduate from an industry-university cooperative program have met their expectations. Twenty-two of the 23 participants would like to continue the partnership with the universities in the future, whereas one participant would like to consider this dependent on a particular situation.

From the industry partners’ perspective, being involved in this partnership does benefit them in various ways. According to interview questions $3 \& 4$, Table 3 shows the codes that have been analyzed from participants' answers; they were categorized into five themes.

The industry responses are grouped into five themes, which identify the primary benefits received by industry from the cooperative education program.

Interview Question 3: What do you think about university-industry partnerships overall?

Interview Question 4: What benefits does your company get from partnering with a university? What benefits do you get personally from the partnership? What are the drawbacks of this partnership?

\section{Table 3}

\begin{tabular}{|l|l|c|l|}
\hline \hline Theme \# & \multicolumn{1}{|c|}{ Themes } & Code & \multicolumn{1}{|c|}{ Related Codes } \\
\hline & Create & A & Credibility; \\
Theme \#1 & Credible Labor & X & Target great talent; \\
& Pool & AE & Priority of getting the talent; \\
\hline
\end{tabular}




\begin{tabular}{|c|c|c|c|}
\hline & & $\begin{array}{l}\text { E } \\
Z \\
\text { L } \\
\text { S } \\
\text { P } \\
\text { D } \\
\text { F }\end{array}$ & $\begin{array}{l}\text { Access to a great recruiting Source; } \\
\text { Get potential candidates; } \\
\text { Green student; } \\
\text { Motivated and has potential; } \\
\text { Better qualified candidates; } \\
\text { Engaged; } \\
\text { Get students with big potential }\end{array}$ \\
\hline Theme \#2 & New Energy & $\begin{array}{l}\mathrm{N} \\
\mathrm{O} \\
\mathrm{Q} \\
\mathrm{C} \\
\mathrm{Y} \\
\mathrm{J} \\
\mathrm{AA} \\
\mathrm{AJ} \\
\mathrm{AI} \\
\mathrm{AK} \\
\mathrm{K}\end{array}$ & $\begin{array}{l}\text { New ideas; } \\
\text { New perspectives; } \\
\text { New insights; } \\
\text { Fresh energy; } \\
\text { Freshness of perspective; } \\
\text { Improve business; } \\
\text { Build strong leadership bench; } \\
\text { Fill positions; } \\
\text { Share thoughts; } \\
\text { Better ideas; } \\
\text { Would like to be transferred; }\end{array}$ \\
\hline Theme \#3 & $\begin{array}{l}\text { Company } \\
\text { Loyalty }\end{array}$ & $\begin{array}{l}\mathrm{W} \\
\mathrm{AB}\end{array}$ & $\begin{array}{l}\text { Career loyalty; } \\
\text { Willing to engaged in the same company } \\
\text { from the entry level } \\
\text { Shape future leaders; }\end{array}$ \\
\hline
\end{tabular}




\begin{tabular}{|c|c|c|c|}
\hline & & $\begin{array}{l}M \\
G\end{array}$ & $\begin{array}{l}\text { Grow their career in the company; } \\
\text { Don't have any other influences from other } \\
\text { companies }\end{array}$ \\
\hline Theme \#4 & $\begin{array}{l}\text { Altruistic } \\
\text { Social } \\
\text { Responsibility }\end{array}$ & $\begin{array}{l}\text { B } \\
\text { AG } \\
\text { AL } \\
\text { AC } \\
\text { AD } \\
\text { R }\end{array}$ & $\begin{array}{l}\text { Playing forward } \\
\text { First-handed feedback; } \\
\text { Accredit for institutions; } \\
\text { Positively impact the community; } \\
\text { Share trends with school/ students } \\
\text { Giving Back }\end{array}$ \\
\hline There \#5 & $\begin{array}{l}\text { Mutual } \\
\text { Learning }\end{array}$ & $\begin{array}{l}\text { AF } \\
\text { AM } \\
\text { T } \\
\text { U } \\
\text { V }\end{array}$ & $\begin{array}{l}\text { Cutting edge of what is being taught } \\
\text { Mold them for the future } \\
\text { Positively impact the community } \\
\text { Share trends with school/ } \\
\text { Enhance learning experience }\end{array}$ \\
\hline
\end{tabular}

\section{Theme 1: Create Credible Labor Pool}

By analyzing the answers from all participants, the benefit that appeared most frequently was about creating a credible labor pool for the industry partners. Frye and Eicher (2006) stated that the hospitality industry has encountered the labor shortage from the baby boomers and the generation X; a gap the millennial generation may fill. With the incorporation into university hospitality programs, better qualified candidates are being generated into the labor pool. Codes that made up this theme were: credibility; target 
great talents; priority of getting the talents; access to a great recruiting source; get potential candidates and better qualified candidates. Representative statements to these effects are as follow:

- I think it's a great program and gives the university a lot of credibility. It's always good to have this relationship between the university and the industry. There is a lot of great talent out there and by keeping this relationship we are able to target these talents easier. (Participant \#1)

- Access to a great recruiting source. (Participant \#3)

- It's an excellent tool for companies to get students with big potential. I know that university is by far the best resource to find amazing personalities. (Participant \#5)

- The company can accomplish tasks that otherwise may never be done and if the results are great the company will make every possible effort to hire the professional on a permanent basis. (Participant \#11)

- It provides with not just qualified candidates but also a network of university administrators and alumni, can offer various resources to benefit organization. (Participant \#14)

- We get the opportunity of finding quality and talented motivated young individuals, plus a useful partnership with accredited institutions. (Participant \#19)

- The benefits my company gets from partnering from a university is we get to see what is out there in terms of new talent. (Participant \#21) 
- The greatest benefit is in being able to recruit talented individuals that are focused on learning and succeeding in the hospitality. (Participant \#22)

The partnership between the universities and the industry was found by previous researchers. Students who graduate from a university have a stronger education background and learning skills. Breen (2002) implied that to obtain professional personnel is the most basic motive for industry organizations to establish the partnership with universities. Also mentioned by Leslie and Richardson (2000), the partnership brings potential candidates with high capability and do not need re-training. In another word, cooperative education program provides students with pre-training opportunities, which help them to be more prepared for their career and reduce the training process when they get started. As a result, this partnership does bring professional and potential talents for industry partners, and it creates a credible labor pool for the entire industry. The partners would like to participate in it, especially when they have witnessed the affirmative outcomes. As time goes on, the partnership can grow stronger and more reliable.

\section{Theme 2: New Energy}

Another apparent benefit according to participants' responses is the new energy brought by students in the Cooperative program. Students are under centralized educational courses, so their critical thinking may form an academic perspective, which could be different from the industry perspective. Also, the students are influenced by the high-technology progress; their perspective would be more advanced, and may be a better 
fit in regards to the new trend. The codes which made up this theme include: freshness of perspective; insights to new ideas; new energy and new resources; new and innovative approaches to the organization; new skills and perspectives. Representative statements to this effect are as follow:

- Students bring an energy and a freshness of perspective of their work that is valuable. Sometimes students have ideas that would be difficult for someone employed in the industry to have devised single-handedly. This is a beautiful new perspective offered by the students. (Participant \#2)

- Employees that are engaged, because this is what they want to do as a career. (Participant \#3)

- These partnerships bring new resources to the table, new energy as well as opportunities for research/focus groups from the future workforce. (Participant \#7)

- One benefit is finding the next group of managers and training them to the betterment of the industry. Another benefit is having new eyes look at your systems and perhaps add new concepts and thoughts. (Participant \#9)

- The recruiters get an overall sense of reward by allowing student to gain practical experience and bringing new approaches to the organization. (Participant \#13)

- Internships benefit the company in trade and technology, bringing goods to the market faster through partnership, research, training, apprenticeships. (Participant \#20) 
Businesses always want to grow in the long-run, so new concepts are the key for them to make progress. Students are young and energetic; they have passion, energy, interests, and new ideas. Industry partners find the value in these qualities, and seek graduate students who possess them. This partnership is valuable because the students could help the business grow in many ways.

- It gives businesses insights to new ideas they may have not contemplated. Students bring fresh energy that can be turned into exciting new products or processes. We also benefitted from someone coming in and analyzing weaknesses that we weren't necessarily aware of or how to fix them. (Participant \#6)

- Being able to have students who bring a new perspective into the company, ideas on what is current now, and how this can be used to make our business more successful. (Participant \#17)

Leslie and Richardson (2000) pointed out that the partnership offers opportunity to bring someone "who is not steeped in tradition" into the organization. From the response, the participants have been benefiting from the graduate students of the program by accomplishing the great outcome. Since most students do not have much real-world experience, their perspectives may not be valued by industry employees who have worked for many years. This is one reason why new energy is essential. The new concept brings change which is always a crucial step for the business to grow and to survive in the long run. Hence, new ideas have been encouraged and considered as a benefit for the industry. 
Moreover, the hospitality business is a global business that demands travel a lot more than other industries. Students, as younger professionals, are willing or can travel around the world.

- We are a global company so anywhere in the world they would like to transfer to. (Participant \#4)

The business would like to transfer new candidates to the global branches because it is an excellent opportunity for candidates to learn and grow. Graduated students are more flexible with their schedule, and they are very ambitious. Travel is a good option for them, and this match is just what the global organization is looking for.

\section{Theme 3: Company Loyalty}

Five of the 23 participants indicated that cooperative partnership helps the company to build up company loyalty with younger professionals. Those industry organizations who participate in the partnership with universities are usually the first organizations graduate students get accepted into upon their graduation, so there is little influence from other companies. Industry organizations would like to take those students as their potential leadership bench. The codes which made up this theme were: career loyalty, willing to engage in the same company from the entry level, shape future leaders, grow their career in the company, don't have any other influences from other companies. Representative statements to this effect are as follows:

- Our organization benefits by getting great students that start in our entry level positions and grow into our management team and executive team members. (Participant \#4) 
- It's an excellent tool for companies to get students with big potential, that can learn the culture of the company from zero and do not have any other influences from other companies. (Participant \#5)

- They are the future of the hospitality, so by listening to them we learn what we need to change within our hiring offices in order to attract young professionals. (Participant \#15)

- From the partnership, we are able to hire quality employees that grow thin the company. (Participant \#16)

Industry partners are willing to recruit students graduate from the Cooperative program not only for their current background, but also for their future. From the long-term perspective, industry partners prefer to have potential candidates and help them to grow within the company. In another words, they are doing it for themselves as well because they bring great talent to the business. Another interpretation of their answers is that companies are willing to attract the young professionals by listening to their ideas and their opinions. In other words, companies could have more opportunities to get connected with students by participating in the partnership, and present their companies to increase their reputation and attract more talent to their company.

\section{Theme 4: Altruistic Social Responsibility}

Five participants indicated that the partnership with the university is a mutual beneficial program that not only shares the resources with each other, but also expresses their altruistic social responsibility, as well. The codes which made up this theme include: 
first-handed feedback, accredit for institutions, positively impact the community, share trends with school/ students. Representative quotes to this theme are the follow:

- The right partnership can grow and create great new things for our community and society. (Participant \#17)

- $\quad$ They are the future of the hospitality, so by listening to them we learn what we need to change within our hiring offices in order to attract young professionals. (Participant \#15)

- Some benefits that we get from internships include: increased productivity, new skills a perspective, finding future employees, improving supervisory and leadership skills, giving back to the community, low coast labor and support of students. (Participant \#20)

By partnering with universities, industry organizations get the opportunity to showcase their social responsibility and give back to both the local community and the entire industry as a whole.

\section{Theme 5: Mutual Learning}

The Cooperative Education program not only brings benefits for industry partners, but it also provides a mutual learning opportunity for industry organizations and universities, as well. Students are the future of the industry, so it is crucial for the industry to know what they have learned so far and what they need to improve in the future. At the same time, the universities will be given up-to-date information about the industry to keep their teaching material in line with current trends. Codes which made up this theme are: cutting edge of what is being taught, mold them for the future, students are the future of the business, positively impact the community, share trends with 
school/students, enhance learning experience. Representative quotes refer to this theme are the following:

- Internships, research projects, being on the cutting edge of what is being taught. Also, just the sharing of resources with the university. (Participant \#10)

- It is beneficial to us as a company because we get to experience first-hand how students feel about the hospitality industry what they believe will happen after college; while at the same time it's a wonderful opportunity for students to get their "foot in the door" with big-name companies they otherwise may not have been given an opportunity with. (Participant \#15)

- University - industry partnership are great. These students are the future of our business. Having the ability to work with them hands on and mold them for the future is very rewarding. (Participant \#18)

- $\quad$ The company benefits by being able to positively impact the community and being able to share trends with school/students that will enhance their learning experience and preparation for the job seeking experience. (Participant \#22)

Overall, the partnership can be considered to be a process of mutual learning; not only is the industry and universities sharing resources with each other, but they are learning from each other in order to improve the industry overall. 
Twenty-two of the 23 participants would like to continue the partnership with the universities in the future, whereas one participant would like to consider this dependent on the particular situation.

\section{CHAPTER V}

\section{DISCUSSION AND CONCLUSION}

The results demonstrate five different benefits perceived by the industry partners as a result of participating in a Cooperative Education program. Found by previous research, the Cooperative Education program has been considered to be a positive option for industry recruitment. This benefit is the one highly identified by most industry participants. Graduated students not only have an enhanced educational background, but their learning skills and personalities are better developed, which are highly anticipated by the industry partners. Better qualified candidates not only accelerate the hospitality industry to achieve professionalism, but also enhance the standards of the entire industry. The reliable partnership can be maintained long-term, which is beneficial for the present, as well as the future.

Indicated by Leslie \& Richardson (2000), the partnership benefits the industry by bringing the organizations with new people, "who is not steeped in tradition”. This study found that industry partners would like to continue the partnership with the universities because they receive benefits of new energetic employees. Graduate students are new to the industry, and they have the ability to provide new views and opinions. Not only do their fresh perspectives, endless passion, and strong ambition fit the industry culture, but they also help organizations to grow better. By recruiting and listening to students, the 
industry can receive new insight of the business and the industry, which could be an incredible improvement or bring about significant change. The industry considers new graduates as "fresh energy", which indicates that students brings new perspectives beyond traditions and restrictions. To "think out of box" has become a strength of the graduated students. Less working experience and more structured knowledge base sometimes inspire them in a different way, which generates new insights and fresh ideas for the industry. In addition, graduated students as a younger generation has higher technology capability, which is another attractive character that is looking for by the industry. From the participants' responses, it is obvious to see that this is what they desire and what they welcome. The industry can be better developed with new views.

Also mentioned by Leslie \& Richardson (2000), the partnership reduces turnover problems. Creating a corporate culture and becoming attractive to students could result in a lower employee turnover rate. The participants responded with "increase company loyalty”. Pre-training company can be the first gate of entering the industry for graduated students. By experiencing the real industry operations, they build up their confidence with the company and grow stronger with the company simultaneously. After the students' graduation, the company has greater chance to be their first choice, and this is the beginning of their loyalty. Choose the company and grow with the company will be a concept of the graduate students, which encourage them to stay and to contribute instead of lingering around. For the company, it is also a great chance to obtain qualified talents and advance them in future positions of the company.

A benefit of showing social responsibility is found by this study. Company is born for benefits. However, beyond benefits, what makes the company to be a better one is 
how they giving back to the society. Building up the partnership with universities is a great access for the industry partners to express their social responsibility. By generating greater profits with better qualified candidates, the company also offers a better service for the society and more opportunities for students. Nowadays, the brand image not only expresses a name of a product, but also its value. Social responsibility can be counted as a part of value, which express the company's value in the society and how they benefit the society to get higher recognition.

The last benefit is called mutual learning experience. Participants consider the students as "the future of the industry", which expressed their desire and their expectation. The cooperative education program is established by universities and industry organizations, so that both sides share resources and grow together. Universities are able to get access to the newest trend of the industry and keep their course material updated with the current trend; whereas industry organizations not only get access to a great labor pool with the best candidates' lists, but also get the opportunity to listen to their opinions that may create lots of possibilities of hospitality industry. This process is a mutual learning experience, which maximize the benefits for both sides from a long-term perspective.

To think in a profitable perspective, by identifying these five benefits, universities can use this as a marketing strategy and take the initiatives to establish a partnership with industry organizations. Moreover, the partnership is a faster way to get higher public recognition for both universities and industry organizations. The Cooperative Education program can be a win-win program for all parties-students, academia and industry partners. All parties can receive benefits from the program by learning from each other. 


\section{Interesting Findings}

Prior to this study, lower labor cost was considered as a key benefit for industry partners. However, there was only one participant who mentioned lower labor cost, which is a surprising result. In the future, a quantitative research is recommended to find out if this benefit is perceived by more industry partners.

In addition, there is only one participant who responded with drawbacks of this partnership. The participant stated that some students do the internship only to earn college credits rather than consider it as a valuable working preview. This improper attitude leaves negative impression for the industry organizations. They expect students to enhance their attitudes and be more proactive during the internship.

\section{Limitation}

This study was designed as a qualitative research study, thus, the results do not express the population's opinion as a whole. For future research, a qualitative study should be conducted to survey more participants to validate findings, and to identify additional benefits to industry.

\section{Future Studies}

In the future, a quantitative study is recommended to validate or dismiss the results of this exploratory qualitative first step. Studies with a larger, more representative, and possible international sample may be conducted to identify additional benefits to industry. Other studies may seek to compare the benefits perceived by individuals in different sectors of the industry, or in different geographical locations. Experiment with a before and after implementing a marketing plan based on the benefits. Compare the performance of the universities with different partnerships. Discover the drawbacks of the partnership. 


\section{REFERENCES}

Achterberg, C. L., \& Arendt, S. (2008). Qualitative research methods. In Monsen, E. (ed.) Research: Successful approaches. (3rd ed.) Chicago: American Dietetic Association.

Becher, T. (1999). Professional Practices: Commitment and Capability in a Changing Environment. London: Transaction Publishers.

Bereday, G. (1973). University For All, International Perspectives on Mass Higher Education. California: Jossey-Bass Publishers.

Braun, Virginia and Clarke, Victoria (2006) Using thematic analysis in psychology. Qualitative Research in Psychology, 3 (2). pp. 77-101

Breen, H. (2002). An investigation of professional development education for tourism and the hospitality employees through university and industry cooperative education partnerships. Journal of Teaching in Travel \& Tourism, 2(3), 1.

Breen, H., \& Hing, N. (2002). Improving competitiveness through cooperation: Assessing the benefits of cooperative education partnerships in gaming management. Gaming Research \& Review Journal, 6(1), 57.

Busby, G. (2005) Work experience and industrial links. In D. Airey and J. Tribe (Eds.), An International Handbook of Tourism Education. London: Elsevier.

Busby, G. D., \& Gibson, P. (2010). Tourism and the hospitality internship experiences overseas: A british perspective. Journal of The hospitality, Leisure, Sport \& Tourism Education (Oxford Brookes University), 9(1), 4-12. doi:10.3794/johlste.91.244

Chang, D., \& Chu, P.University-industry cooperation in action: A case study of the integrated internship program (IIP) in taiwan. Journal of The hospitality \& Tourism Education, 21(1), 6.

Coco, M. (2000). Internships: A try before you buy arrangement. S.A.M. Advanced Management Journal, 65(2), 41-43.

Crawford, E. F. (2013). Diagnostic efficiency of the AUDIT-C in U.S. veterans with military service since september 11, 2001. Drug and Alcohol Dependence, 132(1-2), 101; 101-106; 106.

De Geus, A. (1997). The Living Company. Harvard Business Review, 75 (2), 51-59. Duke, C. (1992). Adult and Continuing Higher Education. In B. Clark \& G. Neave (Eds.), The Encyclopedia of Higher Education, Oxford: Permagon Press. 
Dickerson, J. P., \& Kline, S. F. (2008). The early career impact of the co-op commitment in the hospitality curricula. Journal of Teaching in Travel \& Tourism, 8(1), 3-22. doi:10.1080/15313220802252183

Drucker, P. (1997). Looking Ahead: Implications of the Present. Harvard Business Review, 75 (5), 18-32.

Fidgeon, P. R. (2010). Tourism education and curriculum design: A time for consolidation and review? Tourism Management, 31(6), 699-723. doi:10.1016/j.tourman.2010.05.019

Frye, W. D., \& Eicher, C. (2006). THE BENEFITS OF SCHOOL-TO-WORK INITIATIVES FOR THE HOSPITALITY ORGANIZATIONS: FORMULA FOR SUCCESS IN PENNSYLVANIA. Consortium Journal of The hospitality \& Tourism, 11(1).

Gillin, L.M., Davie, R.S. and Beissel, K.R. (1984), "Evaluat- ing the career progress of Australian engineering graduates”, Journal of Cooperative Education, Vol. 23, pp. 53-70.

Gruman, J., Barrows, C., \& Reavley, M. (2009). A the hospitality management education model: Recommendations for theeffective use of work-based learning in undergraduate management courses. Journal of The hospitality \& Tourism Education, 21(4), 26-33.

Gryski, G. S., Johnson, G. W., \& O’Toole, Jr., L. J. (1987, Summer). Undergraduate Internships: An empirical review. Public Administration Quarterly, 11(1), 150-170.

Hase, S. (1997). Copperative education partnerships: Australian university in a turbulent environment. Unpublished doctoral thesis, Southern Cross University, Lismore.

Harris, R. \& Jago, L. (2001). Professional accreditation in the Australian tourism industry; an uncertain future. Tourism Management, 22, 383-390.

Hemmington, N. (1999). Themes and Issues in Continuing Professional Development. Continuing Professional Development, 2 (2), 47-51.

King, B. (1994). Cooperative education for the hospitality and tourism students: An Australian case study. Australian Journal of The hospitality Management, 1(2), 17-24.

Kiser, J. W., \& Partlow, C. G. (1999). Experiential learning in the hospitality education: An exploratory study. Journal of The hospitality and Tourism Education, 11(2/3), 70-74. 
Kwortnik, R.J. (2003). Clarifying "fuzzy” the hospitality management problems with depth interviews and qualitative analysis. Cornell Hotel and Restaurant Administration Quarterly, 44(2), 117-129

Lam, T., \& Ching, L. (2007). An exploratory study of an internship program: The case of hong kong students. International Journal of The hospitality Management, 26(2), 336-351. doi:10.1016/j.ijhm.2006.01.001

Leslie, D., \& Richardson, A. (2000). Tourism and cooperative education in UK undergraduate courses: Are the benefits being realised? Tourism Management, 21(5), 489.

Martin, A., Fleming, J., Ferkins, L., Wiersma, C., \& Coll, R. K. (2010). Facilitating and integrating learning within sport studies cooperative education: Exploring the pedagogies employed by students, academics and workplace supervisors.

Marlin-Bennett, R. (2002). Linking experiential and classroom education: Lessons learned from the American University-Amnesty International USA summer institute on human rights. International Studies Perspective, 3, 384-395.

Petrillose, M. J., \& Montgomery, R. (1998). An exploratory study of internship practices in hospitality education and industry's perception of the importance of internships in the hospitality curriculum. Journal of Hospitality and Tourism Education, 9(4), 4651.

Powers, T., \& Riegel, C. (1993). A bright future for hospitality education: Providing value in the 21st century. Hospitality Research Journal, 17(1), 295-308.

Roberts, T. G. (2003). An interpretation of Dewey's experiential learning theory (Report No. SO 035 392). Gainesville, FL: University of Florida. (ERIC Document Reproduction Service No. ED481922)

Sigala, M., \& Baum, T. (2003). Trends and issues in tourism and hospitality higher education:Visioning the future. Tourism and Hospitality Research, 4(4), 367-376.

Solnet, D., Robinson, R., \& Cooper, C. (2007). An industry partnerships approach to tourism education. Journal of The hospitality, Leisure, Sport \& Tourism Education (Oxford Brookes University), 6(1), 66-70.

Strauss, A. \& Corbin, J. (1998). Basics of qualitative research: procedures and techniques for developing gounded theory. Thousand Oaks, CA:Sage.

Teichler, U. (1992). Occupation Structures and Higher Education. In B. Clark \& G. Neave (Eds.), The Encyclopedia of Higher Education. Oxford: Permagon Press. 
Tesone, D. V., \& Ricci, P. (2005). Job competency expectations for hospitality and tourism employees: Perception of educational preparation. Journal of Human Resources in Hospitality \& Tourism, 4(2), 53-64.

Van Hoof, H. B. (2000). The international internship as part of the the hospitality manage- ment curriculum: Combining work experience with international exposure. Journal of The hospitality and Tourism Education, 12(1), 6-75.

Wallace, J. R., \& Ipson, G. Y. (1992). Workforce development: Business/university partnerships. Economic Development Review, 10(1), 83.

Waryszak, R. (1999). Students' expectations from their cooperative education placements in the the hospitality industry: An international perspective. Education \& Training (London), 41(1), 33-40.

Wilson, B. (1997). Australia. In M. Green (Ed.), Transforming Higher Education Views from Leaders Around the World. Arizona: Oryx Press.

World Council and Assembly on Cooperative Education (1987). In W. Longworth, (Ed.)Cooperative Education: Cooperation between industry and advanced education teaching programs. Canberra: CTEC. 